American Journal of Pharmaceutical Education 2017; 81 (7) Article 6209.

\title{
COMMENTARY
}

\section{Creating Student Organizations to Promote Careers in Academic Pharmacy}

\author{
Erika L. Vuernick, PharmD, ${ }^{a}$ Daniel R. Kennedy, $\mathrm{PhD}^{\mathrm{b}}$ \\ ${ }^{a}$ University of Rhode Island, Kingston, Rhode Island \\ ${ }^{\mathrm{b}}$ Western New England University, Springfield, Massachusetts \\ Submitted December 6, 2016; accepted December 18, 2016; published September 2017.
}

Keywords: academic pharmacy, student careers

The high rate of faculty vacancies is an issue that has plagued schools and colleges of pharmacy throughout the United States for the past 10-15 years. A 2002 survey by the American Association of Colleges of Pharmacy (AACP) found a severe faculty shortage, with an average of six open positions per program. ${ }^{1}$ While there has been a slight improvement, the most recent data from AACP found there were 466 vacant faculty positions across 121 programs, or about four vacancies per program. ${ }^{2}$

There are two main reasons for the high number of faculty vacancies. The first is the sizable increase in the number of graduates from pharmacy programs over the past 20 years (from both new programs and class size expansion at legacy programs). In order to maintain a suitable faculty to student ratio, new faculty positions were opened. The second is faculty turnover. An average of three pharmacy practice members resign annually per pharmacy program, ${ }^{3}$ and these shortages create an increased workload and more stressful environment for existing faculty members, which can lead to further resignations and worsen the problem. ${ }^{4}$

The quality of health care within the pharmacy field depends on the production of qualified, intelligent, and professional new graduates, which requires qualified educators. Numerous efforts - at both the national and local levels - have been made to address the need to attract and develop more highly qualified faculty members. One of the first steps was the enactment of the Pharmacy Education Aid Act in 2003, which included a student loan repayment program to encourage students to serve as faculty members. ${ }^{5}$ A second major push was the development of the Walmart Scholars program in 2005 through the joint efforts of Walmart and AACP. Over the past 11

Corresponding Author: Daniel R. Kennedy, Department of Pharmaceutical and Administrative Services, Western New England University College of Pharmacy, 1215 Wilbraham Road, Springfield, MA 01119-2684. Tel: 413-796-2413.

E-mail: dkennedy@wne.edu

(Note: At the time of manuscript submission, author Erika L. Vuernick was a student at Western New England University.) years, more than 750 students, residents, and fellows have been selected to attend the AACP annual summer conference and its pre-conference Teaching Seminar to facilitate their exploration of a career path in academia. Additional national initiatives have been created as well, including a 2-hour program at ASHP Midyear Clinical Meeting designed to provide information to students, residents, and practicing pharmacists regarding academic careers. ${ }^{6}$ Local efforts at exposing and encouraging students to pursue a career in academic pharmacy have also been developed. Many PGY-1 residencies and fellowships include a teaching certificate program, which, although varied, generally provide some educational theory and an opportunity for residents to teach pharmacy students in a didactic or laboratory class. Additionally, several pharmacy programs across the United States offer an elective didactic course or an elective APPE rotation in academic pharmacy. ${ }^{7,8}$

Each of these steps is helping to increase the number of students pursuing a career in academia, yet the shortage of faculty still exists. One major drawback of most of the available opportunities is that they have a relatively late entry point in a future pharmacist's education and training. For example, teaching certificate programs will only impact students who have already chosen to pursue, and were subsequently selected for a residency, occurring too late in the training process for the majority of pharmacy graduates to be exposed to the teaching opportunity. As an academic pharmacy community, we owe it to our students to plant the seed of a potential career in academia early on in their schooling, so more graduates have adequate exposure to academics as a career option.

We believe that the best way to foster interest in academic pharmacy career opportunities would be to start student chapters of AACP at schools and colleges of pharmacy. By establishing student chapters, students would have a low-risk, low-investment entry point into the world of academia, which would be likely to attract a small percentage of students at each program who otherwise would not have considered academic pharmacy as a career option. It is interesting to note that academic pharmacy is 


\section{American Journal of Pharmaceutical Education 2017; 81 (7) Article 6209.}

fairly unique among pharmacy occupations in its lack of a student organization to help mentor and guide students into these career paths. The creation of student AACP chapters would allow students to explore academic careers, similar to the way in which one with a potential interest in hospital pharmacy may join SSHP (Student Societies of Health-System Pharmacy) or one who desires to own or operate their own community pharmacy may join their college chapter of NCPA (National Community Pharmacist Association).

Student chapters would provide learners with a multitude of opportunities to educate themselves on the world of academia and to assist them in taking the first steps toward becoming a faculty member. Chapters may invite academic speakers for the students, install a panel of pharmacy administrators for guidance, and create mentor-mentee pairs for students who are interested in research and scholarship and have aspirations of becoming faculty members in the future. In addition, the creation of these chapters may encourage its student members to serve in available college-wide committee roles for learners.

The formation of student chapters of AACP would be in support of the Academy's strategic plan by helping to increase membership within the organization. Ideally, student chapters would send representatives to the AACP Annual Meeting to present research and interact with chapters from other schools. Attending an AACP meeting early in one's career has a number of benefits, for both the Academy and the attendee. These would be early opportunities for students to become involved in the Academy and make a connection with the organization that would hopefully lead them to continue to attend throughout their careers. It also allows students to interact with deans, department chairs, and faculty from other institutions, allowing them an opportunity to network with the people who may be hiring them in the future.
The creation of AACP student chapters is a potentially valuable avenue to encourage students to pursue a career in academic pharmacy. It would be available to students to join the Academy early in their pharmacy school training, and be a low-risk first step to allow them to gain insight into academic life. Creating student chapters of AACP would require little to no financial backing from AACP, and would benefit the Academy with increased membership and meeting attendance. As the faculty shortage remains high, AACP student chapters have the potential to play a key role in attracting and developing a new generation of faculty educators.

\section{REFERENCES}

1. American Foundation for Pharmaceutical Education. Acute shortage of faculty at US pharmacy schools threatens efforts to solve nation's pharmacist shortage. July 29, 2003. http://www.prnewswire. com/news-releases/acute-shortage-of-faculty-at-us-pharmacyschools-threatens-efforts-to-solve-nations-pharmacist-shortage70844342.html.

2. American Association of College of Pharmacy. Institutional research brief number 18: vacant budgeted and lost faculty positions academic year 2014-15. http://www.aacp.org/resources/research/ institutionalresearch/Documents/IRB\%20No\%2018\%20-\%20Faculty $\% 20$ Vacancies.pdf.

3. Carter O, Nathisuwan S, Stoddard GJ, Munger MA. Faculty turnover within academic pharmacy departments. Ann Pharmacother. 2003;37(2):197-201.

4. Taylor CT, Berry TM. A pharmacy faculty academy to foster professional growth and long-term retention of junior faculty members. Am J Pharm Educ. 2008;72(2):Article 32.

5. Ives TJ, Elenbaas RM. Pharmacy Education Aid Act of 2003 introduced in Senate. ACCP Report. May 2003;22(5):1.

6. Baia P, Strang A. An elective course to promote academic pharmacy as a career. Am J Pharm Educ. 2012;76(2):Article 30. 7. Spooner JJ, Kennedy DR. An elective course to foster interest in academic pharmacy career opportunities. Am J Pharm Educ. 2017;81(1):Article 13.

8. Draugalis JR, DiPiro JT, Zeolla MM, Schwinghammer TL. A career in academic pharmacy: opportunities, challenges, and rewards. Am J Pharm Educ. 2006;70(1):Article 17. 